\author{
Jacek Strojny \\ University of Agriculture in Krakow \\ e-mail:rrstrojn@cyf-kr.edu.pl \\ ORCID: 0000-0002-0577-377X
}

\title{
AN ASSESSMENT OF THE COMPETITIVENESS OF POLISH EXPORTS TO GERMANY IN RESPECT OF SECTORS BASED ON MARKET ATTRACTIVENESS AND MARKET POSITION
} OCENA KONKURENCYJNOŚCI EKSPORTU POLSKIEGO DO NIEMIEC W UJECIU SEKTOROWYM NA PODSTAWIE KONCEPCJI ATRAKCYJNOŚCI RYNKU I POZYCJI RYNKOWEJ

DOI: $10.15611 /$ pn.2019.8.19

JEL Classification: M31, F14, F19

Summary: The study is aimed at assessing international competitiveness of Polish exports on a selected market. The research was conducted at sectoral level. The research method employed is the attractiveness and position indicator (AP-indicator). The AP-indicator adopts the portfolio models approach. The method enabled to quantify target market's attractiveness and the competitive position of Polish exports on that market. The research is based on EUROSTAT statistics and covers the period of 2010-2018. According to the results, all the widely defined categories of products delivered by Polish exporters to German may be considered as competitive. The most promising part of Polish exports on the considered market are the SITC $0+1$, SITC 5, SITC 6+8, and SITC 7 class, characterised by the extraordinary market growth and high exports' dynamics. The study is dedicated only to assessing competitiveness. Explaining the drivers of the competitiveness is beyond the scope of the research.

Keywords: Polish exports, international competitiveness, AP-indicator, competitiveness indicator.

Streszczenie: Badanie ma na celu oszacowanie konkurencyjności międzynarodowej polskiego eksportu na wybranym rynku. Badanie prowadzono na poziomie sektorowym. W studium wykorzystano metodę nazywaną wskaźnikiem atrakcyjności i pozycji rynkowej (wskaźnikAP). Technika ta odwołuje się do metod portfelowych. Umożliwiła ona kwantyfikację atrakcyjności rynku docelowego oraz pozycji konkurencyjnej polskiego eksportu na ten rynek. Badanie bazuje na danych EUROSTAT i obejmuje lata 2010-2018. Stosownie do wyników analizy wszystkie szeroko zdefiniowane klasy produktów oferowane przez polskich eksporterów na 
rynku niemieckim można uznać za konkurencyjne. Jako najbardziej perspektywiczne należy postrzegać klasy produktowe SITC $0+1$, SITC 5, SITC 6+8 oraz SITC 7, charakteryzujące się ponadprzeciętnym tempem wzrostu rynku oraz wysoką dynamiką eksportu. Studium ma na celu jedynie ocenę konkurencyjności. Poszukiwanie czynników konkurencyjności nie jest przedmiotem badania.

Słowa kluczowe: polski eksport, konkurencyjność międzynarodowa, wskaźnik AP, miernik konkurencyjności.

\section{Introduction}

One of the components of the strategic decision taking process is the analysis of the external operating environment. The purpose of that analysis is the identification of the opportunities and threats which affect the implementation of the objectives of a business. The analysis of the external environment may lead to a strategic shift at the exporting enterprise.

Recognising and controlling the external environment enables to optimise a firm's assets [Saloner, Shepard, Podolny 2001]. A company strategy needs to accommodate both the internal characteristics and the qualities of the external environment. Initially, key elements of the strategic analysis were the firm's strengths and weaknesses [Ansoff 1965]. However, over the years the strategic management interest tends to swing from the firm towards the industry. Nevertheless, both the internal characteristics of an enterprise such as its strengths and weaknesses as well as the external context defined by environmental threats and opportunities are central to strategic thinking.

Strategic management combines concepts from different fields. According to Hill, Schilling and Jones [2017], an analysis of the external environment should cover an examination of the industry environment, the country environment, and the macro-environment. Thus from the perspective of that study, undertaking an examination of the industry environment is the most interesting. This requires an evaluation of the competitive structure of a particular industry, and because most markets are international in their nature, the industry analysis involves assessing the impact of international economic exchange on competition within the considered industry. The outcome of an industry analysis may reveal some recommendations with reference to the allocation of company resources.

The external and internal analyses enable to develop strategic alternatives and to make available an evaluation of the considered alternatives through providing criteria for such an assessment. For gaining the competitive advantage and the creation of capabilities to compete based on a firm's internal resources see [Collis, Montgomery 1995]. The concept of the creation of future competitive advantage on the basis of the firm's core competence was presented by Hamel and Prahalad [1994]. Saloner, Shepard and Podolny [2001] acknowledge that rearrangements of 
the external environment may become the most serious challenge for an industry. Some changes of the external environment result from the evolution of the market, hence the analysis of external context covers in particular industry characteristics such as market analysis and competition study. That evaluation should be converted into action through the strategy redefinition and afterwards its implementation. A proper reaction to the change of the external environment should result in gaining competitive advantage and achieving higher performance of the firm [Doyle 1994].

The study focuses on changes in one of the components of the business external environment such as the international market. For the sake of monitoring and measuring the competitiveness of the Polish economy at sectoral level, the attractiveness/position indicator (AP-indicator) was employed. That measure was used to assess the international competitiveness of Polish industry sectors on the German export market in the context of selected EU markets which are most important for Polish exporters. The competitive position of the Polish industry sectors on German market was compared to the Czech, United Kingdom, French, Italian, Dutch, Swedish, and Slovak markets. The research method compares the export results of the Polish economy with the development of the importing markets of the considered EU countries. Hence the overall purpose of the AP-indicator application was the competitiveness evaluation on the exporting market from the perspective of an industry sector. The study is confined to an assessment of the competitiveness. The explanation of the reasons for competitiveness diversification as well as looking for drivers of that phenomenon is outside the scope of that analysis.

\section{The research methodology}

\subsection{Literature review}

Various authors reason that the main challenge for businesses arises from the interdependence between the internal conditions and the external environment. In particular, competitiveness is a very complex concept with no agreed definition in the economic literature. The competitiveness evaluation within the study invokes the concept that relates to trade aspects of the economic competition. In this sense, the economic rivalry is reflected in particular in the ability to gain and maintain market share in some international markets.

The AP-indicator allows for considering both the export achievements of an industry sector and the development of the importing markets in question. This analytical tool uses the concept of the portfolio methods. Portfolio techniques were extensively utilised in multi-business companies for individual products evaluation and strategy formulation [Buzzell 2004]. As stated by Griffin [2016], portfolio techniques are used by diversified companies to decide which business to engage in and how to conduct these businesses to maximise the results of operations. 
The most commonly known portfolio method referred to as the BCG Matrix, is the Market Share - Market Growth concept developed by the Boston Consultancy Group [BCG 1971]. Another widely used portfolio management technique is the GE Business Screen (GE BS). The BCG Matrix is a scheme for a product relative position assessment in relation to its market growth rate and the company's market share. This analytical technique is based on the assumption that a considerable firm's market share in fast growing markets create business opportunities. The aim of the analysis using the BCG Matrix is a support for finding some recommendations in respect of the firm's resources distribution among diversified businesses. Businesses that have a relatively small market share in markets which are not expected to grow do not hold much economic promise and are not worth to be invested in. On the other hand, products that have a considerable share in fast growing markets should be supported by significant investment to ensure their outstanding position.

The GE Business Screen is a more complex approach to portfolio analysis than the BCG technique [Hunger, Wheelen 2014]. Two dimensions are used to classify businesses in three categories. This results in a nine-cell matrix. The businesses are evaluated along dimensions that are called industry attractiveness and competitive position. Both dimensions are determined by a broad list of factors. The industry competitive position, in particular, is influenced by market share. Other determinants of the competitive position include product quality, technological know-how, price competitiveness, operating costs, and quality service network. The overall industry attractiveness is defined by market growth, market size, capital requirements, and competitive intensity. The GE Business Screen method could be perceived as a kind of SWOT analysis applied to the management of diversification strategy of a firm. The outcome of the analysis leads to recommendations based on the idea that the company should invest in a business which is characterised by the attractive industry and outstanding competitive position [Whittington 2001]. This could be perceived as well as a suggestion to concentrate on operations which enable to utilise the business's strengths and where markets are encouraging [Davis, Devinney 1997].

A modification of the competitive strength matrix, such as the GE Business Screen is the Life Cycle Matrix developed by A.D. Little. The industry attractiveness dimension was replaced by the product life cycle phase. Mikkola [2001] stated that this concept may be used to support managers balancing the products portfolio. Owen and Harrisson [1995] proposed a modification of the portfolio method in the form of a matrix with two axes. The vertical dimension of that matrix invoked the coherence of the critical success competences needed to be successful in the business with the firm's core capabilities. The horizontal axis deals with the fit between the business prospects and the basic competence of the firm.

Nicholls [1995] proposed an idea of the Mission and Core Competences portfolio decision matrix. This approach provides for assessment of the fit between the firm's mission (on the vertical axis) and the company's core competences (on the horizontal axis). The dimensions of the matrix are divided into two halves featuring a good fit 
and a poor fit of the investigated issue. Some additional adaptations of the concept of the portfolio and decision matrix were submitted, for example, by Majluf and Hax [1983], Devinney and Stewart [1988], Nguyen, Séror and Devinney [1990].

\subsection{The method and data}

The study aimed to assess the international competitiveness of Polish industry sectors on the German importing market. Polish exports and the German importing market are classified according to Standard International Trade Classification (SITC). The SITC classification is used to classify the exports and imports of a country to enable comparing selected countries and time periods. The analysis is based on EUROSTAT data. The traded goods for purposes of the study have been classified according to the rules adopted by EUROSTAT:

- $\quad$ SITC 0+1 - Food, drinks and tobacco.

- $\quad$ SITC 2+4 - Raw materials.

- $\quad$ SITC 3 - Mineral fuels, lubricants and related materials.

- SITC 5 - Chemicals and related products.

- $\quad$ SITC 6+8 - Other manufactured goods.

- $\quad$ SITC 7 - Machinery and transport equipment.

- $\quad$ SITC 9 - Commodities and transactions not classified elsewhere in the SITC.

The trade flows were investigated in the form of exports and imports values (denominated in euros). The work took into account two periods, one of which was 2018 while the reference period was 2010.

In general it may be said that the study of competitiveness is conducted at sectoral level; because of being classified according to its consisting of similar products, in broad terms, a SITC class could be equated with an industry sector. The competitiveness evaluation of Polish exports was conducted according to SITC class using a concept formulated by Viaene and Gellynck [1989; 1995; 1997] and Gellynck, Viaene and Heene [2001]. These authors developed an analytical framework called the attractiveness/position indicator that is useful for the assessment of the international competitiveness of economy sectors.

The AP-indicator invokes the portfolio models analytical framework to organize information. Basically, the method uses information related to market attributes such as a products category market share and its growth over a considered period, as well as a certain goods class market size and that market's growth. The importance of the market size and market growth in developing the business strategy was demonstrated, for example, by Dunne, Roberts and Samuelson [1988], Aaker [2001], Saloner, Shepard and Podolny [2001]. In economic literature there is broad agreement about the relevance of the market share and market share growth in forming a firm's strategy [Porter 1980; 1985; 1987; 1990; 1996].

Invoking listed market characteristics, the AP-indicator is built based on two dimensions, namely attractiveness and position. The attractiveness dimension is conceptualised in terms of market size and market growth. The position component 
is based on market share and market share growth factors. Market share is a particular SITC class contribution to total imports (or exports). Market share growth is the percentage change in that indicator over the study period.

The AP-indicator is evaluated for the importing market as well as for the exporting market. As every dimension's estimation is based on two variables, the entire process includes a calculation of eight components. The final evaluation of a particular SITC class competitiveness consists in the comparison of the importing market evolution and the development of Polish exports on the target market.

At every stage of the AP-indicator building, the consecutive issues are evaluated according to three levels of intensification of the phenomenon: high, medium and low. These categories of the AP-indicator $(\zeta)$ for a particular aspect of the research problem are defined as follows:

- High $-\zeta>\frac{1}{m \times n} \sum_{i} \sum_{j} Z_{i j}-$ an assessment of a SITC class is not lower than the mean value obtained for all SITC classes.

- Medium $-\frac{1}{m \times n} \sum_{i} \sum_{j} Z_{i j} \geq \zeta \geq 0,5 \times \frac{1}{m \times n} \sum_{i} \sum_{j} Z_{i j}$ - the score lay in the range between the mean value of the estimate and $50 \%$ of that value for all SITC classes.

- Low $-\zeta<0,5 \times \frac{1}{m \times n} \sum_{i} \sum_{j} Z_{i j}$ - the score is lower than $50 \%$ of the mean estimate for all SITC classes,

where: $\zeta$ - estimate of an AP-indicator component; $i$ - number of SITC classes $(i=1,2, \ldots k) ; j$ - number of a market $(j=1,2, \ldots n) ; Z_{i j}-$ a particular market value (exporting or importing).

Each arrangement of two components results in a matrix of $3 \times 3$. For this reason, the consecutive investigated aspects are distinguished according to the low, medium and high score. Since the matrix dimensions are arranged in descending order, a particular SITC class on the importing market as well as on the exporting market is assessed according to the three levels. Highly scored items are located above the matrix diagonal, the medium score is assigned to an element located on the diagonal of the matrix, from top left to bottom right, and the low score is designated for a SITC class situated below the main matrix diagonal. The appraisal of the importing market and exporting market is carried out under the same rules. Hence both the results of the attractiveness and position valuations are placed in separate $3 \times 3$ matrices. Competitiveness quantification is derived from the comparison of AP-indicators evaluating the importing market and the position of exports on the target market. A SITC class is competitively bracketed if the score of exports development was at least the same or exceeded the assessment of the importing market. 


\section{Results and discussion}

In 2018 the total Polish exports of commodities totalled 221.0 billion euros, and imports 226.1 billion euros. ${ }^{1}$ For Polish exporters, the European market is the most important one. Polish exports to European countries in 2018 amounted to 196.6 billion euros (89.0\% of total exports), whereas imports from that region amounted to 157.7 billion euros (69.7\% of total imports). The European Union remains Poland's principal economic partner. The EU countries were responsible in 2018 for 177.6 billion euros of exports. In terms of the share of a particular country in Polish total exports in 2018, the most important markets in the European Union were: Germany (28.2\%), Czechia (6.4\%), the United Kingdom (6.2\%), France (5.5\%), Italy (4.6\%), the Netherlands (4.5\%), Sweden (2.8\%), and Slovakia (2.6\%). The study of competitiveness on the most crucial exports markets compares the position of Polish exports on the German market with the development of other (listed above) significant markets for Polish exporters.

The attractiveness of the German importing market (assessed considering the aforementioned EU markets), which is defined by market size and market growth is shown in Figure 1. Products placed in the table above the diagonal from top left to bottom right (SITC $0+1$, SITC 5, SITC 6+8, SITC 7) are highly scored and form a particularly attractive market segment. Medium attractiveness could be attributed to the SITC $2+4$ and SITC 3 class. The low attractive part of the German market comprised exporters' goods qualified as those belonging to the SITC 9 class.

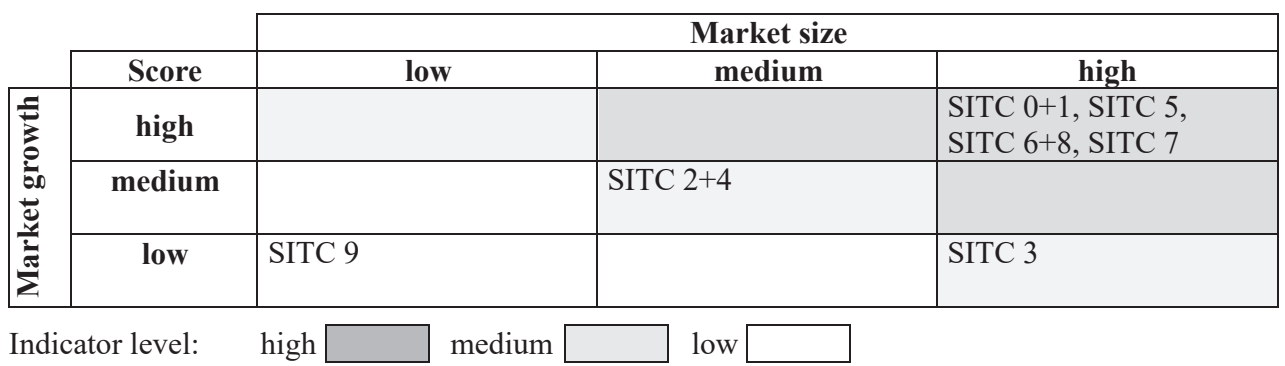

Fig. 1. Attractiveness assessment of the German importing market

Source: own calculations based on EUROSTAT data, 2019 year.

The position valuation of products belonging to consecutive SITC classes is based on market share gained by a class and its market growth. The assessment of the position on the German importing market is featured in Figure 2, where the high position was assigned to the SITC $0+1$, SITC 5, SITC 6+8, and SITC 7 class. The medium score was attributed to any SITC class, while the poor evaluation on importing market was given to SITC $2+4$, SITC 9 and SITC 3 class.

1 Central Statistical Office data. 


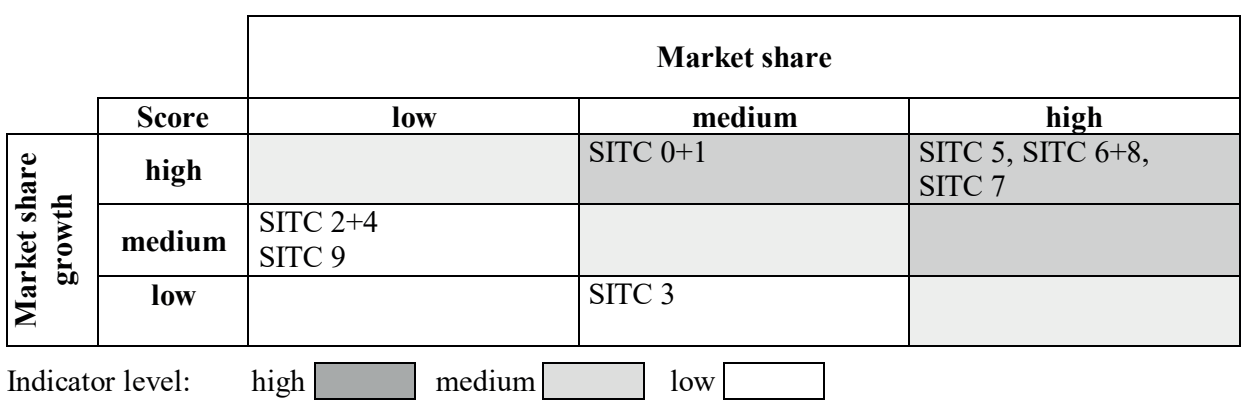

Fig. 2. Position evaluation of products' groups on the German importing market

Source: own calculations based on EUROSTAT data, 2019 year.

Figure 3 shows the arrangement of attractiveness and position indicators, which enables the overall evaluation of the German importing market. According to the analysis, the high score of the AP-indicator was assigned to the SITC 0+1, SITC 5, SITC $6+8$, and SITC 7 class. The low scores were allocated to goods belonging to SITC 2+4, SITC 3, and SITC 9 class. On the German importing market, no SITC class was evaluated using the medium score of the AP-indicator.

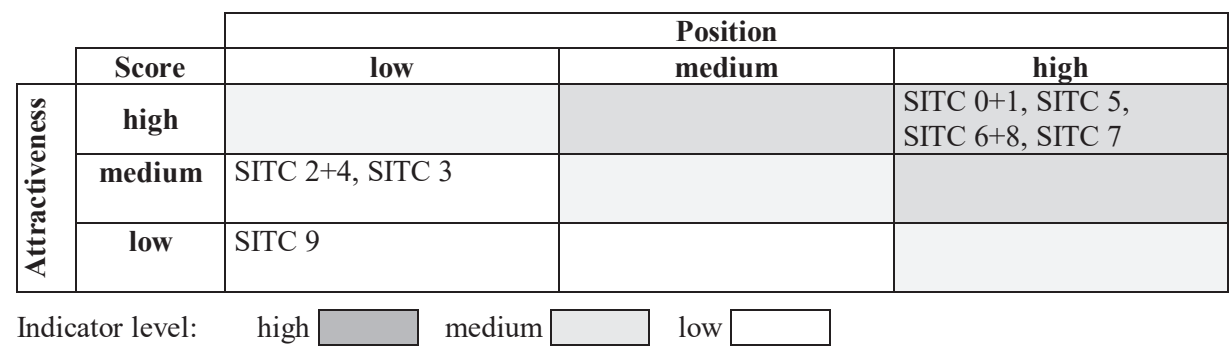

Fig. 3. The arrangement of attractiveness and position indicators of the German importing market Source: own calculations based on EUROSTAT data, 2019 year.

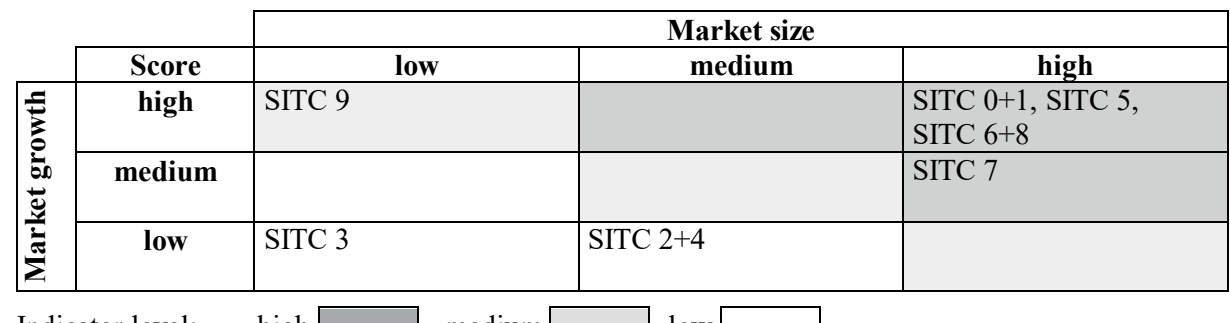

Fig. 4. Attractiveness assessment of the Polish exports on the German importing market

Source: own calculations based on EUROSTAT data, 2019 year. 
For the purpose of making the assessment of Polish exports on the German market, a similar procedure to the evaluation of importing market evaluation is applied. Figure 4 pictures the outcome of the estimation of the exporting market attractiveness. The valuation is based on exporting market size and market growth indicators. In accordance with the analysis, Polish exports belonging to the SITC $0+1$, SITC 5, SITC 6+8, and SITC 7 class are highly attractive on the target market. Medium attractiveness was attributed to the SITC 9 class. Exports belonging to the SITC 3 and SITC $2+4$ class were rated as being low in attractiveness.

Assessment of the position of Polish exports on the German market referred to the market share and market share growth dimensions (Figure 5). A combination of these indicators resulted in the high level of the AP-indicator for the SITC 0+1, SITC 5 , SITC $6+8$, and SITC 7 class. The medium score of the position was attributed only to the SITC 9 category. According to the evaluation results, the low position score was assigned to the SITC 3 and SITC $2+4$ class.

\begin{tabular}{|c|c|c|c|c|}
\hline & & \multicolumn{3}{|c|}{ Market share } \\
\hline & Score & low & medium & high \\
\hline \multirow{3}{*}{ 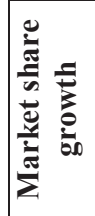 } & high & SITC 9 & $\begin{array}{l}\text { SITC 0+1, } \\
\text { SITC } 5\end{array}$ & $\begin{array}{l}\text { SITC } 6+8, \\
\text { SITC } 7\end{array}$ \\
\hline & medium & & & \\
\hline & low & $\begin{array}{l}\text { SITC 2+4, } \\
\text { SITC } 3\end{array}$ & & \\
\hline
\end{tabular}

Indicator level: $\quad$ high $\square$ medium $\square$ low $\square$

Fig. 5. Position evaluation of Polish exports on the German importing market

Source: own calculations based on EUROSTAT data, 2019 year.

\begin{tabular}{|l|c|l|l|l|}
\cline { 2 - 5 } \multicolumn{1}{c|}{} & \multicolumn{2}{c|}{ Score } & \multicolumn{1}{c|}{ low } & \multicolumn{1}{c|}{ medium } \\
\hline \multirow{2}{nyyyy}{} & high & & & \multicolumn{1}{c|}{ high } \\
\cline { 2 - 5 } & & & $\begin{array}{l}\text { SITC 0+1, SITC 5, } \\
\text { SITC 6+8, SITC 7 }\end{array}$ \\
\cline { 2 - 5 } & medium & & SITC 9 & \\
\cline { 1 - 4 } & low & $\begin{array}{l}\text { SITC 2+4, } \\
\text { SITC 3 }\end{array}$ \\
\cline { 2 - 5 } & & & & \\
\hline
\end{tabular}

Indicator level: high $\square$ medium $\square$ low

Fig. 6. The arrangement of attractiveness and position indicators of the Polish exports on the German importing market

Source: Own calculations based on EUROSTAT data, 2019 year.

The comparison of the attractiveness and position ratings enabled a comprehensive evaluation of Polish exports on the German market (Figure 6). According to that 
assessment, the high score of the AP-indicator was attributed to the SITC $0+1$, SITC 5 , SITC $6+8$, and SITC 7 class. The only item designated to the medium category was the SITC 9 class. The low score was assigned to the SITC $2+4$ and SITC 3 class.

The assessment of the performance of Polish exports on the German market was achieved due to the similarity of the AP-indicators of the exporting and importing markets. The results of the study of competitiveness are presented in Figure 7. Any product which received (for exporting market) at least an equal score as the rating gained for importing market, was classified as competitive.

The only product category where the exporting market assessment outdid visibly the importing market rating is the SITC 9 class. Nevertheless account should be taken of the small share of that kind of exports in the total Polish exports. Assessments of other SITC classes were equal to both aspects of the market, hence all the considered product categories that were offered by Polish exporters on the German market could be recognised as competitive. Nevertheless, the SITC 0+1, SITC 5, SITC $6+8$ and SITC 7 classes represent both the high growth of the importing market, as well as the high dynamics of Polish exports on that market.

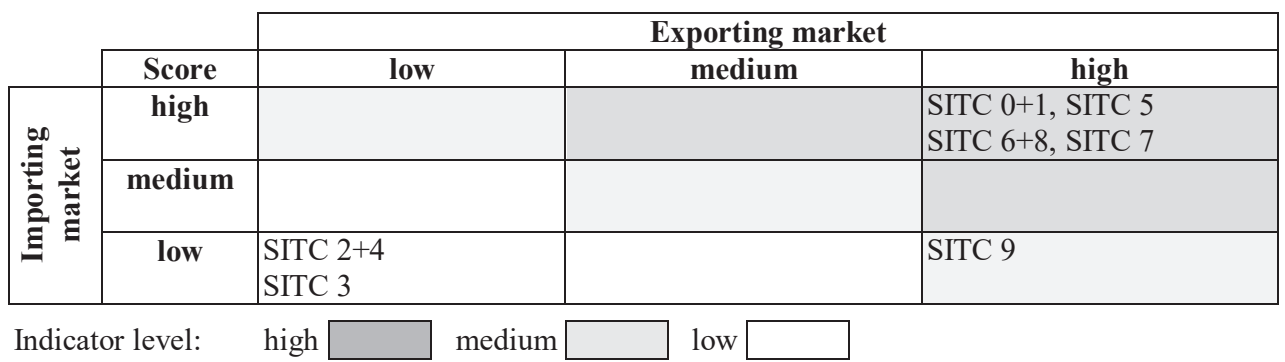

Fig. 7. Competitiveness assessment of Polish exports on the German market

Source: Own calculations based on EUROSTAT data, 2019 year.

The outcome of the study coincides with the assessment by Misztal [2013] of Polish-German trade. This author points out that from the sectoral point of view, the trade is evolving in the direction of the gradual increase of dispersion of the product structure of Polish exports to Germany. Additionally, the structures of Polish exports to Germany and imports from Germany are morphing into each other. Kacperska [2013] acknowledged that income elasticity of Polish exports to Germany showed a high variability (the considered period was 2005-2012). A more detailed approach to the analysis of competitiveness of exports to Germany at sectoral level was presented by Pellegrin [2001].

A substantial volume of Polish exports is based on comparative advantages (for instance, food, timber and articles of wood) and can be justified by the Heckscher-Ohlin trade theory [Ziółkowski 2013]. Koszewski [2011] presents an analysis of export consortia as a determinant of Polish exports. 
The sectoral structure of international trade is changing due to the process of global value chains' fragmentation - a term coined by Jones and Kierzkowski [2000]. The increasing fragmentation makes the gross export category that is commonly used in trade statistics of little value for analysis of the competitive position of sectors.

The literature explains the trade flows between relatively similar partners such as Poland and Germany by referring to New Trade Theories (NTT) [Grubel, Lloyd 1975]. In the NTT approach the issue of competitiveness and its aspects is an important part of the analysis.

\section{Conclusions}

The research dealt with the problem of the assessment of sectoral competitiveness on the international market referring to the attractiveness and position indicator concept. The arrangement of AP-indicators of the importing and the exporting markets implies that Polish exports destined for the German market are competitive in all product categories defined by the SITC classes. The top competitive position is held by goods belonging to the SITC 9 class where the exports dynamics exceed market development. However, these products do not represent a significant share of Polish exports on the German market. The most promising section of Polish exports on the considered market are the SITC $0+1$, SITC 5, SITC 6+8, and SITC 7 class characterised by the extraordinary market growth and exports dynamics at a similar pace.

The application of the AP-indicator enabled to quantify the German market attractiveness and the competitive position of Polish exports on that market. The research established the basis for the investigation of the determinants of competitiveness. The study contributes to management research by investigating the external environment of the Polish economy from the perspective of a widely defined economy sector.

\section{Bibliography}

Aaker D.A., 2001, Strategic Market Management, John Wiley \& Sons Inc, New York.

Ansoff I.H., 1965, Corporate strategy, McGraw-Hill, New York.

BCG, 1971, Growth and Financial Strategies, Boston Consultancy Group, Boston.

Buzzell R.D., 2004, The PIMS program of strategy research: A retrospective appraisal, Journal of Business Research, vol. 57, pp. 478-483.

Collis D.J., Montgomery, C.A., 1995, Competing on resources: Strategy in the 1990s, Harvard Business Review, vol. 73, no. 4, pp. 118-128.

Davis J.G., Devinney, T.M., 1997, The Essence of Corporate Strategy: The Theory of Modern Decision Making, Allen \& Unwin, Sydney. 
Devinney T., Stewart D., 1988, Rethinking the product portfolio: A generalized investment model, Management Science, vol. 34, pp. 1080-1095.

Doyle P., 1994, Marketing Management and Strategy, Prentice Hall International, London.

Dunne T., Roberts M.J., Samuelson L., 1988, Patterns of firm entry and exit in US manufacturing industries, The Rand Journal of Economics, vol. 19, pp. 495-515.

Gellynck X., Viaene J., Heene A., 2001, Measuring Competitiveness at Meso Level. Dag van het Wetenschappelijk Economisch Onderzoek in Vlaanderen, http://hdl.handle.net/1854/LU-147048 (2019.06.30).

Griffin R., 2016, Fundamentals of Management, Cengage Learning, Boston, MA.

Grubel H.G., Lloyd P.J., 1975, Intra-Industry Trade: The Theory and Measurement of International Trade in Differentiated Products, London.

Hamel G., Prahalad, C.K., 1994, Competing for the Future: Breakthrough Strategies for Seizing Control of your Industries and Creating the Markets for Tomorrow, Harvard Business School Press, Boston, MA.

Hunger D., Wheelen T., 2014, Essentials of Strategic Management, Pearson Education Limited, Harlow.

Hill Ch., Schilling M., Jones G., 2017, Strategic Management Theory: An Integrated Approach, Cengage Learning, Boston, MA.

Majluf S., Hax A., 1983, The industry attractiveness-business strength matrix in strategic planning, Interfaces, vol. 13, pp. 54-71.

Jones R., Kierzkowski H., 2000, Globalization and the Consequences of International Fragmentation, [in:] Dornbusch R., Calvo G., Obstfeld M. (eds.), The Festschrift in Honor of Robert A. Mundell, MIT Press, Cambridge, MA.

Kacperska E., 2013, The influence of international trade with Germany, the agro-food trade in particular, on the Polish GDP size, Problemy Rolnictwa Światowego, Warsaw University of Life Sciences, vol. 13(28), pp. 1-10.

Koszewki R., 2011, Konsorcja eksportowe jako instrument aktywizacji eksportu dla małych i średnich przedsiębiorstw, Wydawnictwo Uniwersytetu Gdańskiego, Gdańsk.

Mikkola J.H., 2001, Portfolio Management of R\&D projects: Implications for innovation management, Technovation, vol. 21, no. 7, pp. 423-435.

Misztal P., 2013, Ewolucja polsko-niemieckiej wymiany handlowej na przełomie XX i XXI wieku, Biuletyn Instytutu Zachodniego, nr 146, Instytut Zachodni, Poznań.

Nguyen T., Séror A., Devinney T., 1990, Diversification strategy and performance in Canadian manufacturing firms, Strategic Management Journal, vol. 11, pp. 411-418.

Nicholls J., 1995, The MCC decision matrix: A tool for applying strategic logic to everyday activity, Management Decision, vol. 33, no. 6, pp. 4-28.

Owen G., Harrison T., 1995, Why ICI chose to demerge, Harvard Business Review, vol. 95, pp. 132-142 .

Pellegrin J., 2001, The Political Economy of Competitiveness in an Enlarged Europe, Palgrave Macmillan, Houndmills.

Porter M.E., 1980, Competitive Strategy: Techniques for Analyzing Industries and Companies, Free Press, New York.

Porter M.E., 1985, Competitive Advantage: Creating and Sustaining Superior Performance, Free Press, New York.

Porter M.E., 1987, From competitive advantage to corporate strategy, Harvard Business Review, vol. 65 , no. 3 , pp. $43-59$.

Porter M.E., 1990, The Competitive Advantage of Nations, MacMillan Press, London.

Porter M.E., 1996, What is strategy?, Harvard Business Review, vol. 74, no. 6, pp. 61-78.

Saloner G., Shepard A., Podolny J., 2001, Strategic management, John Wiley \& Sons Inc, New York.

Viaene J., Gellynck X., 1989, Distribution Structure and Image of the Belgian Meat Industry in France: Image and Marketing Strategy, Report II, Ghent University, Ghent. 
Viaene J., Gellynck X., 1995, Market Integration and the Small Country Case: Pressure on the Belgian Meat Sub-Sector, IAMA-Congress: The New Trade Environment, Paris.

Viaene J., Gellynck X., 1997, Impact of Globalisation on Competitiveness of the Belgian Frozen Vegetables Industry, [in:] Loader R.J., Henson S.J., Traill W.B. (eds.), Globalisation of the Food Industry: Policy Implications. Reading, University of Reading, Reading, pp. 509-524.

Whittington R., 2001, What is Strategy - and Does it Matter? Cengage Learning EMEA, London.

Ziółkowski K., 2013, The activity of Polish Export companies as a factor stimulating the development of Poland's merchandise exports to Germany, Gospodarka Narodowa, 4(260), pp. 65-82. 